\title{
FOREIGN MARKETS ENTRY MOTIVES AND STRATEGIES OF POLISH EXPORTERS
}

\author{
Jaroslav Ďad’o, Jan W. Wiktor, Agnieszka Żbikowska
}

\section{Introduction}

The paper aims to assess the strategies of Polish exporters in entering foreign markets. The paper is comprised of three parts. The first part presents strategies of international marketing, its elements, types, nature, and conditions - the premises and motives for internationalization of a company. It is mainly a synthetic reflection based on the review of literature. It is a starting point in presenting a research project concept. The second part shows the methodology of an empirical study. The third part consists of analysis and generalised overview of the results of the study on marketing strategies of Polish exporters. This broad study focuses on identifying strategies that are being employed by Polish exporters in the process of internationalization and the motives behind international activities. Such definition of the main goal of the article touches upon the notion of international growth of companies and constitutes attempt to find a specific answer to the questions regarding strategies of internationalization, questions that are critical in the contemporary, global, open economy. We focused our attention on two important and fundamental aspects - motives for expansion and strategies of entering foreign markets. This empirical study is the result of the Ministry of Science and Higher Education grant for a team of researchers from the Marketing Department of Cracow University of Economics. The Project entitled "Corporate Marketing Strategies on International Markets" (N N115 042937) was implemented under the author's supervision in 2009-2011 [22].

\section{A Theoretical Approach to Foreign Markets Entry Strategies \\ 1.1 Reasons for Corporate Internationalization}

In small open economies all firms have to interact with the international market if they are to become internationally competitive. Internationalization is dependent on the firm's ability to carry out strategies in the international marketplace and the actual skills in international business operation [7].

Geographical expansion of business activities over national borders is the definition of internationalisation of business activities. The reasons for business activities in an abroad market are the focus of internationalization theory. Motives and entry strategies are the focus of international marketing. The fundamental reason for exporting, in most firms, is to make money. But it is not the only motive for international market entry. It can be found through various literary sources a list of motives for moving to international markets. Hollensen identified two categories of motivation for internationalization (see Tab. 1): proactive motives (focused to exploiting unique competences as, for example, special technological knowledge) and reactive motives (as reaction to pressure in its home market). The list of motives presented in conclusions of research and in textbooks in not complete. Special situation was in transformed economies of East Europe in 90s. Managers searched foreign market where real cash flow in trade relations existed. Motives are usually presented only from an export perspective [10], [12], [13]. But similar motives are driving power for other internationalization strategies too. Firms looking to international/foreign market usually see opportunity in that market. 


\begin{tabular}{l|ll}
\multicolumn{1}{c|}{ Proactive motives } & \multicolumn{1}{c}{ Reactive motives } \\
\hline$-\quad$ Profit and growth goals. & - & Competitive pressure. \\
$-\quad$ Managerial urge. & - & Domestic market: small and saturated. \\
$-\quad$ Technology competence/unique product. & - & Overproduction/excess capacity. \\
$-\quad$ Foreign market opportunities. & - & Unsolicited foreign orders. \\
$-\quad$ Economies of scale. & - & Extend sales of seasonal products. \\
$-\quad$ Tax benefits. & $-\quad$ Proximity to international customers/ \\
& & psychological distance. \\
\hline
\end{tabular}

"Motives for why companies migrate abroad can be the diversification of sales. If companies consider the home market as unstable they have an effort to eliminate the risk" [2]. Expansion into markets in foreign countries is an excellent way for a company to grow. A motive for internationalization can have its origin in the fact that a company may not be able to reach their goals in their domestic market and therefore has to expand into a foreign market. Business entity applying growth strategy will note sooner or later the necessity to develop its business activities not only in the home market but in foreign market too. Business activities of SME's in international market are phenomena mostly of the last decade [19], [25].

The rationale for internationalization can be divided into three groups [23, p. 25-28]:

- economic reasons,

- market-related reasons (marketing),

- legal reasons (political).

Generally, one can say that companies strive to achieve business results following economic incentives - they hope to increase sales of their products or to reduce production costs per unit. Market (marketing) reasons stem from the need to expand markets and seek out new customers. The last group of reasons relates to legal (political) reasons for company's internationalization. One can note a variety of incentives, but restrictions originating in the host country are of particular interest.

Pertinent literature also cites a division of reasons for foreign expansion which may also include [20]:

- internal stimuli and

- external stimuli.

Internal stimuli are endogenous, companyrelated factors. Here one can point out, for example, a company's command of unique resources (knowledge, product), the desire to develop the company or an excessive accumulation of inventories. External reasons stem from the domestic and foreign business environment (such as a decline in demand in the domestic market, favourable tax regime abroad, an inquiry from abroad).

Hollensen presents the general classification of motives [7]. Specific market situation, category of industry or company life cycle stage are determining for international market entry strategy and motives. For firms located in transforming economy countries one of main criteria for foreign market selection was territorial proximity of that market. The motives and dominant strategies over time in Polish SME's are presented in Tab. 2.

\subsection{International Market Entry Modes}

Undoubtedly, entering foreign markets requires strategic decisions which will shape the company's subsequent activities and its growth opportunities in international markets. The key decision involves determining the entry strategy into a foreign market. In pertinent literature, in parallel with the term "entry strategy", there also exist terms such as "entry mode" and "entry form". A company's strategy of entry into foreign markets can be defined as activities that enable the company to implement a market strategy for its products abroad. This may consist either in pursuing merely marketing activities in foreign markets or production and marketing entirely coordinated by the company or by the company itself in collaboration with others [18]. The entry strategy includes not only the mode of action at the start of operations in a new market, but also the way in which the company operates in this market.

Kotabe and Helsen [9, p. 286-290] point out the criteria underlying the selection of the 


\begin{tabular}{l|l|l|l} 
Period of years & Motives & Dominated strategy & Comment \\
\hline $70-80$ of 20th century. & To receive foreign currency. & Indirect export & $\begin{array}{l}\text { Foreign trade (export and } \\
\text { import) was centralized in } \\
\text { special state companies. }\end{array}$ \\
\hline Start of 90s & $\begin{array}{l}\text { To receive foreign currency and } \\
\text { real cash flow, exploration of } \\
\text { free capacities. }\end{array}$ & Direct export & $\begin{array}{l}\text { Slow liberalization of foreign } \\
\text { trade, with state regulation. }\end{array}$ \\
\hline 2nd half of 90s & $\begin{array}{l}\text { To receive know-how, to explore } \\
\text { cheap resources, effort to find } \\
\text { foreign partner. }\end{array}$ & $\begin{array}{l}\text { Direct export, join ventures, } \\
\text { foreign direct investment }\end{array}$ & $\begin{array}{l}\text { Disturbance of state foreign } \\
\text { trade companies. }\end{array}$ \\
\hline Start of Millennium & To find partner for cooperation. & $\begin{array}{l}\text { Direct export, creation of } \\
\text { alliances }\end{array}$ & Liberalization of foreign trade. \\
\hline Last decade & $\begin{array}{l}\text { To sell license, to survive, to } \\
\text { brave against financial crisis. }\end{array}$ & $\begin{array}{l}\text { The first globally born } \\
\text { companies }\end{array}$ & $\begin{array}{l}\text { Expansion of cyber space, } \\
\text { influences of economic crisis. }\end{array}$ \\
\hline
\end{tabular}

Source: own conception

entry strategy, which can be divided into factors inherent in the company's foreign environment and within the company itself. External conditions underlying decisions surrounding the entry mode include:

- market size and its changes,

- risk of change in the political and economic environments,

- legal regulation of the movement of goods, services, capital and people,

- cultural differences between the home country and the foreign market,

- competitive situation in the foreign market and

- infrastructure available abroad.

The entry mode into new, foreign markets

is also affected by the company's internal conditions, including specifically:

- company's objectives,

- range of control the company wishes to exercise over its foreign operations,

- a company's resources.

Hollensen [8, p. 326-327] identifies two other groups of conditions governing the form of entry into a foreign market. These are:

- desired goals underlying the entry strategy,

- factors affecting the level of transaction costs.

In deciding on the entry strategy into foreign markets, companies must take into account the degree of risk associated with a particular form of entry. Simplifying things, one can assume that the greater the commitment of capital, the greater the risk underlying operations in foreign markets. The entry mode selected by the company also determines the extent of control which the company may have over its operations abroad - this applies in particular to the shaping and monitoring of the use of marketing tools. Depending on the entry strategy into foreign markets, the company has a varied ability to flexibly respond to changes in the environment. For example, direct investment abroad would hinder a quick response to a transformation of market conditions.

The premise underlying the selection of the entry strategy may also be the amount of transaction costs which the company would have to incur while establishing business relationships with foreign partners, in particular with intermediaries operating in foreign markets. Costs of operations in new markets may arise from a search for potential contractors and verification of their credibility, the preparation and contractual negotiation and coordination of cooperation between the company and its business partners. The company must therefore compare the costs of engaging in certain activities (e.g. distribution) on its own with the same if it relied on intermediaries. It should be noted that such specific business knowhow, organizational culture and adopted ways of customer service constituting a competitive advantage may well mean that the fulfilment 
of these functions by external entities will be especially difficult. In such cases, companies will be willing to keep full control over their activities in foreign markets.

Conditions in the domestic market complement the premises underlying the form of entry into foreign markets. They may be determined by the kind of culture perceived from the perspective of power distance. Companies from low power distance countries are more inclined to strike strategic alliances with foreign partners. Entrepreneurs from high power distance cultures will strive for more centralized management. In terms of the domestic environment, one must also indicate actions pursued by the government in the home country, which may, for instance, promote exports (e.g. subsidies for exporters, export credit guarantees), or impede the transfer of capital abroad.

The choice of the export strategy into foreign markets is therefore dependent upon various factors. Analysis of pertinent literature allows for the synthesizing of these conditions into four groups characterized by [14]:

- domestic environment,

- foreign environment,

- company,

- type of transaction.

The main determinants for selection of market entry strategy to the international market (strategies of internationalization) are presented in model - see Figure 1.

\section{Fig. 1: Determinants of choice of strategy of internationalization of companies}

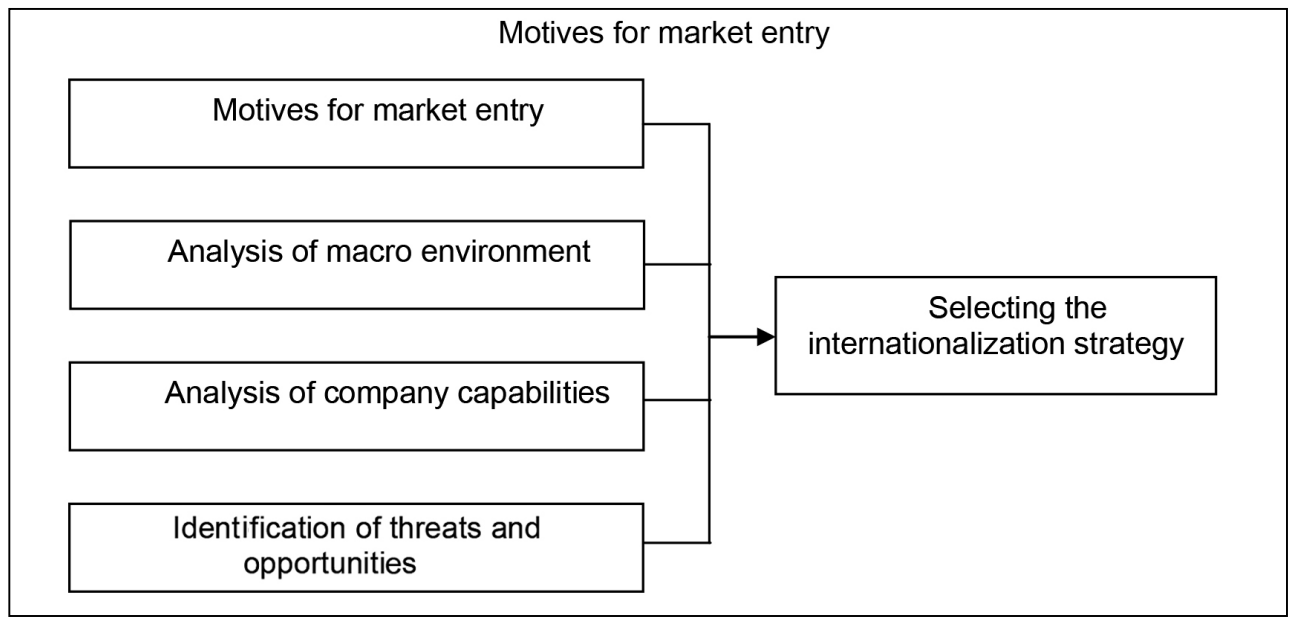

Source: own conception

The wide variety of reasons for choosing a given form of entry justifies the introduction of different classifications of these strategies. Generally, entry modes can be divided into strategies ensuing no investment abroad, and strategies underpinned by capital involvement in foreign markets [15, p. 537]. Strategies in which companies do not invest in foreign markets require of those companies only a small range of control over foreign operations. Investment involvement is associated with a strong need to control activities in international markets.
Another division of strategies, one taking into account the extent of control over the company's activities beyond the borders and the risks undertaken by the company as well as the degree of flexibility inherent in entry forms was proposed by Hollensen. This classification is shown in Figure 2. In it, we can distinguish three groups of strategies: export, contractual, and associated with full commitment to capital.

The above classification does not seem however to fully correspond to the common practice approach to exports. The basic feature 
of this form of entry into the foreign market is the production of goods in the home country and their sale abroad. When the company has only a representative office in the foreign market (sales department abroad, distribution company) - based on this division - one cannot talk about export. The same holds true in the case of direct export, where the company, on its own, looks for buyers of its products and organizes their sale at the same time coordinating these activities from the home country. It is hard not to consider this form as an export strategy, particularly in the macroeconomic context - the context of international exchange.

\section{Fig. 2: Breakdown of entry strategies into foreign markets in terms of the scope of control and the risks borne by the company}

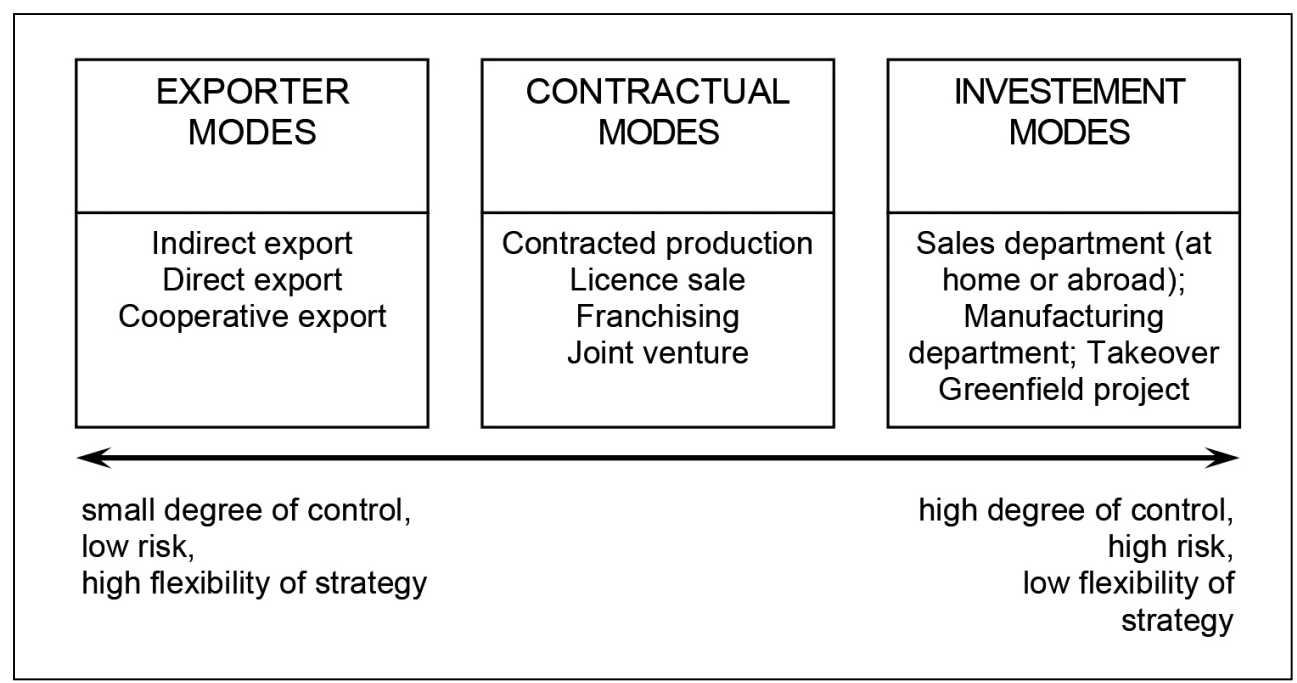

Source: $[8$, p. 317]

This breakdown of entry strategies ignores the location where products offered to foreign buyers are manufactured. This factor can however be important in shaping companies' competitive advantage. Concentration of production in one place allows the company to obtain, among others, economies of scale and lower unit cost. Classification of entry strategies based on the production site, in conjunction with the degree of the company's capital involvement abroad is proposed, amongst others by Kulhavy [11, p. 13]. He breaks down entry forms into strategies relying on:

- domestic production without foreign investment (indirect export and direct export through nonproprietary distribution channels),

- domestic production with capital involvement abroad (direct export with proprietary distribution channels),
- production abroad without investment (sale of licence, franchising, contracted production),

- production abroad with capital involvement (joint venture, proprietary production subsidiary).

The decision to what entry strategy to choose is taken step by step. As stated by Pan and Tse [15], the company will determine at first whether its entry will require capital involvement. Only in the next step, will it select the appropriate form of entry strategy from among a set of strategies involving investments or strategies from among a group without involvement of the company's assets. It should be noted however that many companies opt for the simultaneous use of different entry strategies [16]. 


\section{Methodology of Approach to the Empirical Study}

2.1 Goals and Study Hypotheses

On the cognitive level, this article's goal is:

- The enunciation of the actual premises behind decision making of Polish exporters, who wish to internationalize their businesses and what are their true motives to enter foreign markets,

- To assess the strategies to entering foreign markets, both in context of various forms of export and in exploiting alternative ways to go overseas.

Based on pertinent literature and knowledge of Polish companies' activities in foreign markets, the following hypotheses were formulated:

$\mathrm{H}-1$ The most important group of incentives for Polish companies' internationalization is market related.

$\mathrm{H}-2$ Political and legal incentives help only slightly to encourage Polish companies to enter foreign markets.

$\mathrm{H}-3$ Market size measured in terms of the number of potential customers plays a crucial role as a reason for Polish exporters' entry into foreign markets.

$\mathrm{H}-4$ The size of the company has a bearing on the kind of motivation for internationalization: smaller companies are often guided by defensive reasons while bigger exporters by offensive ones.

H-5 Direct export is the main form of exporting used by Polish companies.

H-6 Polish exporters rarely use entry strategies other than export.

H-7 Apart from exports, direct foreign investment in the form of sale departments abroad and foreign subsidiaries is the most often used mode of entry.

$\mathrm{H}-8 \mathrm{In}$ terms of organisation, the waterfall strategy is the most often used mode of entry into foreign markets.

In the course of analysis, the Pearson's chi-squared test facilitating assessment of interdependences between the variables measured on nominal scales was used. In the subsequent part of the work, in the statistical analysis of relationships between variables, a significance level of $p=0.05$ was taken into account, unless otherwise indicated

The study of a company's internationalization poses serious methodological challenge. There are three points to distinguish: the notion and identity of Polish exporter, methods of realization, and a study sample.

\subsection{The Notion and Identity of Polish Exporter}

In the Polish market there are companies operating according to various business, law, proprietary, capital, and organizational characteristics. A Polish market is an open one and it is an important element of the internal EU market. It is devoid of internal boundaries and duty protection between Poland and EU countries; furthermore it has been normalized in the context of Europe - sphere of exchange mechanisms and entrepreneurial activities. As a domestic market and a common normalized one, it is based on four fundamental values of freedom: freedom of the movement of people, goods, services, and capital. Poland's presence in the EU, accessibility of its domestic market for foreign capital, both European and from outside of the Old Continent, expansion possibilities for home companies in the larger international context, it all forms specific and interesting area of study and empirical scholarship.

The Polish domestic market has become an important one and very attractive, offering positive incentives for all sorts of business activities performed by foreign capital entities. Once such a company has its trade record the REGON system of the National Statistical Bureau - it gains the status of a Polish company, registered in Poland. There is no special significance of the country, from which the capital is coming, or the organizational framework in which it will operate in Poland. The above explains the presence of number of leading European and global companies in the subjective structure of Polish exporters.

The project introduces categories of 'export' and 'exporting company', the latter has different contents in relation to the definition and content of 'export', as well as formal legal regulations. An 'Exporting company' is any entity selling its products not only across border - in the narrow sense, outside of customs territory, but also within its territory, and therefore through the employment of the category of EU supplies (trade within the common market of EU). Consequently, a Polish exporter is every company registered in Poland, according to Polish law, manufacturing its goods in Poland that are, in turn, sold elsewhere, regardless of the origin of the founding capital. Such 
definition helps to overcome Polish exporter 'identity dilemma' and to assess the sample for the study. In literature, part of the research on internationalization, as a study sample takes into account companies in general and focuses cognitive efforts on the functional aspect of export or 'sphere of foreign trade'. This study assumes a dissimilar starting point and a different way of assessing a study sample. The sample constitutes companies for which export and internationalization are stable and a distinct point of reference and is from companies that rank among major exporters.

\subsection{Methods of Realization}

This Scholarly instrumentation was designed to achieve goals of the project, ergo insight into international marketing strategies, including strategy pursued by Polish exporters. The goals were subsumed in two groups quantitative and qualitative. The former reflect a positivist nature, the latter - interpretative. Both approaches meet the fundamental functions of scientific investigation - revealing certain fragment of reality, its clarification, interpretation, and the pointing out of changing patterns and what the future developments would be like. The qualitative strand was dealt with by means of various polling - telephone questionnaire, online poll, standard poll. The questionnaire was used in a pilot research in two large companies that have won international prestige. For the qualitative part, an in-depth interview was linked with direct observation, conducted in the formalized style, using a list of questions and observation notebook.

The methods enabled the acquisition of a vivid picture of the internationalization strategies of Polish exporters, in aspect of their foreign activities, motives, conditions, premises, and profits from entering foreign markets as well as finding out assessment methods, and selecting expansion markets and strategies with presence in the international markets. Such group of issues was investigated by means of a poll, questionnaire, and a direct interview scenario.

\subsection{Study Sample}

The principles of public statistics make it impossible to build a data base containing characteristics of export companies, therefore the selection of a sample proved complex. The problem of conceptualizing 'base of Polish exporters' was solved in the following way.
Quantitative research was conducted among two separate samples. The first one is the group of companies that form 'Polityka' magazine ranking - 100 largest Polish exporters in the 2005-2009 period. This publication, during its five year course was comprised of 173 companies. In this group, the research was realized in two phases. In the first, the questionnaire was sent via internet and by post to the CEO's, managers responsible for marketing, export and international trade. The papers were addressed, in many cases - when the CEO's were foreigners - written in English. All the surveyed companies were addressed by telephone, with the formal request to take part in the research, their officials were informed on the goals and practices and asked for further explanations. The research was conducted between 11'2010-03'2011. In this stage, there were 29 answers out of 173 companies - the ones that form the above mentioned list in 'Polityka' magazine (turn indicator of $16.7 \%$ ).

The second group surveyed were companies in the data base of 'Poland-Export' portal. The portal is mainly dedicated to issues connected with Polish export, analyses of problems, and conditions of growth, trends, and changes. In 2010, 'Poland-Export' had at its disposal the data of 20,000 Polish companies that exported their goods to other countries. The research was online, conducted during 03.2011-05.2011. 'Poland-Export' sent emails (4) with link to questionnaire (electronic), on the site of the Economic University in Krakow. During its course there were 730 visits to the survey, some questions were answered (most often general information on company was provided). For detailed analysis 112 questionnaires were accepted (which stands for $0.6 \%$ of the 'Poland-Export' registered companies). This scant turn indicator can only confirm the critical dilemma in studies on international marketing. Challenges of scientific study and its cognitive requirements form certain premise for constructing questionnaire or list of questions for interview. It may turn out, and this is the most probable case - that the degree of difficulty of the poll plus its complexity was too big a barrier for officials. This type of situation poses an important dilemma, in general, and in particular when it comes to studies in the international environment. Quantitative research involved 141 companies with the identity of 'Polish exporter'. 
Qualitative research was conducted among 13 companies. The choice resulted from two premises. Firstly, these were Polish export companies that had major successes in their international operations.

Success was defined by internationalization indicator, brand recognition, strength of business ties with foreign partners, market position in Poland and abroad, period of exporting activity, etc. Secondly, the companies had an understanding for the research purposes, its characteristics, and expressed willingness to grant access to information on their activities related to foreign markets, and further information required in interviews. Enlisting companies turned difficult and complex with the stage in the study procedure on internationalization of Polish companies. Personal contacts were crucial. A group of 13 companies, subjected to qualitative research, doesn't allow for generalisations, however it forms a premise for detailed identification and in-depth interpretation of international marketing problems [26, p. 54-61]. This specific area of study and its understanding go beyond the framework of this article.

The analysed of the group of 141 companies had the following characteristics:

1. Headcount: 730 employees in both groups of companies. However, distribution of firms was diversified: micro businesses with up to 10 employees accounted for $23 \%$ of the sample, large companies with 250-1,000 employees - $17 \%$, and those with more than 1,000 employees - $13 \%$. The two largest analysed companies had 22,000 and 18,000 employees.

2. The study identified 17 different countries as geographic overseas sales targets. The major countries included Germany (55\% of respondents), the Czech Republic and France (26\%), Russia (25\%) and Ukraine (24\%). The responses confirm the macroeconomic statistics and geography of Poland's foreign trade - after 2009, Poland's major export targets include 1. Germany (26.2\%), 2. France (6.9\%), 5. The Czech Republic (5.8\%), 7. Russia (3.7\%) [22]. This classification reflects the concentration of marketing activities carried out by exporters on one specific market. For most companies such a market generates more than $50 \%$ of export revenues, being the major overseas sales target.
3. The internationalization ratio (WEx) was a significant characteristic of the analysed companies. It expresses the relation between export and total sales revenues. It provides information on the company's international activities and the significance of overseas markets in accomplishing corporate missions. In the case of Polityka's 100 largest exporters, WEx was at the level of $47.5 \%$, and for the group of 112 companies from Poland Export's portal $-44.1 \%$. These figures are comparable, indicating an important role of international activities in both groups of companies. It should be noted, however, that the internationalization ratio was considerably different for the particular entities within E-100 and E-P groups with some of companies starting their international operations (WEx at the level of $0-10 \%$ for $20 \%$ of companies) as well as those which export nearly all their products (90-100\%) (accounting for $8.7 \%$ of entities representing the $\mathrm{E}-100-15$ out of 173 companies).

4. The identity of the E-100 companies is marked by their position in Polish exports. A detailed analysis confirms a large share of 100 largest exporters in Poland's total exports. In 2005-2009, these companies accounted for $1 / 3$ of Poland's exports (36.3\%). The E-100 companies perform a key function in the structure of Polish foreign trade and can be treated as a barometer of economic prosperity and a driver of Poland's economy and its export.

\section{Foreign Markets Entry Modes - In the Light of the Research Results 3.1 Reasons for Entry into Foreign Markets}

The development of marketing strategies in foreign markets is based on the factors that encourage companies to engage in overseas operations. It was therefore important to get to know what kinds of reasons guide the surveyed companies - whether they are market related, economic, political, or legal ones. Having an awareness of the key stimuli may be a valuable source of information for institutions supporting the development of Polish exports and an indication of directions for further action.

The reasons for undertaking export activities are presented in Table 3. The analysed 
Tab. 3: Major reasons for undertaking export activities $(\mathrm{N}=141)$

\begin{tabular}{c|l|c}
$\begin{array}{c}\text { Group } \\
\text { of motives }\end{array}$ & \multicolumn{1}{c|}{ Incentive } & $\begin{array}{c}\text { Balance } \\
\text { of respondents (\%) }\end{array}$ \\
\hline \multirow{4}{*}{$\begin{array}{c}\text { Market-related } \\
\text { motives }\end{array}$} & Size of foreign market & $48.9 \%$ \\
\cline { 2 - 3 } & Enquiry tenders or foreign orders & $44.0 \%$ \\
\cline { 2 - 3 } & Foreign market proximity & $29.8 \%$ \\
\cline { 2 - 3 } & High pace of foreign market development & $18.4 \%$ \\
\cline { 2 - 3 } & $\begin{array}{l}\text { Attempts to pursue hitherto domestic clients who engage in } \\
\text { overseas operations }\end{array}$ & $5.0 \%$ \\
\hline \multirow{3}{*}{$\begin{array}{c}\text { Economic } \\
\text { motives }\end{array}$} & $\begin{array}{l}\text { Possibility of increased production capacity or more effective } \\
\text { use of domestic production potential }\end{array}$ & $46.8 \%$ \\
\cline { 2 - 3 } & Possibility of achieving higher profitability ratios & $31.9 \%$ \\
\cline { 2 - 3 } & $\begin{array}{l}\text { Declining sales of products on domestic market (decreasing } \\
\text { demand, stiffer competition, excess production capacity in } \\
\text { company or industry) }\end{array}$ & $28.4 \%$ \\
\cline { 2 - 3 } & Risk mitigation through diversification & $22.7 \%$ \\
\hline \multirow{2}{*}{ Legal motives } & Favourable regulations in foreign market & $2.8 \%$ \\
\cline { 2 - 3 } & Support offered to overseas operations by Polish institutions & $1.4 \%$ \\
\hline
\end{tabular}

* Exporters could indicate three motives simultaneously, so the presented figures do not add up to $100 \%$.

Source: own research

companies regard market-related (marketing) factors to be decisive, indicating the possibility of acquiring consumers in countries with large populations $(48.9 \%$ of respondents) as well as those in proximity to Poland's territory $(29.8 \%)$. The frequent reason for export activities is the response to prospective clients' interest in the company's products $(44 \%)$.

The economic incentives are slightly less significant - they facilitate a more effective use of production capacity $(46.8 \%)$ and provide an opportunity for generating additional profits (39.1\%).

The political and legal factors turn out to be the least significant reasons for entering foreign markets. Favourable legislation and support offered by Polish organizations seem to be less significant in stimulating overseas business operations. In fact, it confirms the ranking of export drivers presented in professional literatures [13, p. 740].

The analysed companies refer to the size of a foreign market measured by the number of prospective clients as the major reason for entering overseas markets (nearly half of the respondents), while $64 \%$ of them regard
Germany, Ukraine and Russia to be their major export targets. Moreover, $83 \%$ of the companies believe that the potential represented by their major export markets to be a favourable, or a very favourable component of the business environment. The presented data confirm the significance of the market's size as the reason for which Polish companies expand their business operations in overseas markets.

The second significant reason to enter foreign markets is the possibility of increased production capacity or a more effective use of the domestic production potential (nearly half of the responses). This incentive is offensive and internal in character, which is also true of higher profitability ratios. The prospects for additional profits are indicated by nearly $1 / 3$ of companies (this motive ranks fourth in the general classification). Expected higher profits together with increased production capacity and a more effective use of the production potential turn out to be powerful internationalization drivers. The significance of at least one of these factors is stressed by $65 \%$ of the analysed companies, which may testify to the carefully thought through expansion plans in foreign markets in 
most exporting companies and the fact that they adopt a proactive approach in pursuing new markets.

Tender enquiries and overseas orders are the third most significant international driver (44\%). Notably, this is an external and reactive factor which provides an opportunity for low risk export activities, but which also makes such activities dependent on the behaviour of foreign entities. This factor is clearly dependent on the company's size and the number of target countries (Tab. 4). Smaller companies are less inclined to actively engage in pursuing foreign consumers probably due to the lack of qualified staff or scarce financial resources (necessitated, for example, by marketing research projects).
The study indicates that tender enquiries and overseas orders are less significant as foreign expansion drivers in the event of a larger number of foreign countries - export targets. Therefore, experience gained in the process of serving foreign markets seems to encourage companies to actively pursue new consumers.

A significant internationalization driver, recognised by $30 \%$ of respondents, is the foreign market's geographical closeness. The overwhelming majority of companies in this group (92.5\%) state that their largest export market is one of Poland's neighbouring countries (Germany, Slovakia, the Czech Republic, Ukraine or Russia).

\begin{tabular}{|c|c|c|}
\hline $\begin{array}{l}\text { Tender enquiries or overseas ord } \\
\text { on selected features of the compe }\end{array}$ & ternational & n drivers depending \\
\hline Variable & $\begin{array}{c}\text { Value of } \\
\text { the variable }\end{array}$ & $\begin{array}{c}\text { Balance of respondents } \\
(\%)\end{array}$ \\
\hline \multirow{5}{*}{ Number of employees $(\mathrm{N}=133)$} & $1-10$ & $58.1 \%$ \\
\hline & $11-50$ & $54.6 \%$ \\
\hline & $51-250$ & $44.8 \%$ \\
\hline & $251-1,000$ & $26.1 \%$ \\
\hline & above 1,000 & $17.7 \%$ \\
\hline \multirow{5}{*}{$\begin{array}{l}\text { Number of countries to which company ex- } \\
\text { ports its products }(\mathrm{N}=126)^{\star}\end{array}$} & $1-3$ & $29.1 \%$ \\
\hline & $4-6$ & $29.1 \%$ \\
\hline & $7-10$ & $20.0 \%$ \\
\hline & $11-20$ & $12.7 \%$ \\
\hline & above 20 & $9.1 \%$ \\
\hline
\end{tabular}

* With regard to the number of countries, this correlation is significant when $p=0.1$.

Source: own conception

Another motive for starting export activities, initiated by $28.4 \%$ of companies, is the saturation of the domestic market, which makes the sales of products more difficult. The problems result from declining demand, stiffer competition, or excess production capacity in a given industry.

The following motives are indicated as significant by relatively few respondents:

- Risk mitigation through diversified activities (22.7\%).

- High pace of foreign market development (18.4\%).

- Pursuing existing domestic clients who start overseas activities (5\%).
- Favourable regulation in foreign markets (2.8\%).

- Support to overseas operations offered by Polish institutions (1.4\%).

The research study indicates that the frequency of occurrence of some of the factors depends on a given company's membership in the group of Polish largest exporters. These factors are presented in Table 5. As regards the indicated motives which are not included in the Table, no significant differences are recorded between the companies included in „Polityka's” ranking (E-100) and those cited by other sources (E-O). 
Overall, it can be concluded that proactive and internal internationalization drivers are recognised as more significant by companies included in "Polityka's" ranking. The remaining companies more frequently enter foreign markets in response to external factors. Such results confirm the significance of the source of motivating factors in the company's successful market performance. Companies which adopt a proactive approach in conquering foreign markets are likely to generate higher export revenues than the ones which engage in export activities in response to external factors.

Tab. 5: Internationalization factors - E-100 and E-O ( $\mathrm{N}=141)$

\begin{tabular}{l|c|c}
\multicolumn{1}{c|}{ Motive } & E-100 & E-O \\
\hline $\begin{array}{l}\text { Increased production capacity or more effective use of domestic production } \\
\text { potential }\end{array}$ & $65.5 \%$ & $42 \%$ \\
\hline Risk mitigation through diversified activities & $37.9 \%$ & $18.8 \%$ \\
\hline Tender enquiries or overseas orders & $20.7 \%$ & $50 \%$ \\
\hline $\begin{array}{l}\text { Declining sales of products on domestic market (decreasing demand, stiffer } \\
\text { competition, excess production capacity in company or industry) }\end{array}$ & $10.3 \%$ & $33 \%$ \\
\hline
\end{tabular}

Source: own conception

\subsection{The Choice of a Foreign Market Entry Mode}

Consideration given to the degree of engaging company capital outside the home territory and the location of production facilities as two internationalization dimensions is a basis for identifying several different modes of entry into international markets. The available results of research indicate that export is the major entry mode applied by Polish companies [3], [4], [5], [6], [21], [24], [27].

In choosing an export strategy as an entry mode, companies can decide on direct, indirect and collaborative export, or combine different forms of export activity. Figure 3 presents the export modes applied by Polish exporting companies. More than $1 / 3$ of respondents rely exclusively on direct export. This group is dominated by small companies $(52 \%$ of them employing up to 50 employees), which export their products to a limited number of countries $(63.4 \%$ of respondents operate on not more than 6 markets). The characteristics of direct export make this mode more suitable when applied on a smaller number of markets. Interestingly, direct export is mainly applied by small businesses. It is likely that the necessity of engaging a larger part of company assets is compensated for by the possibility of generating relatively higher profits (no agency margins) and maintaining closer relationships with clients. The use of direct export is likely to result from greater opportunities offered by the internet in serving international clients. The use of internet services facilitates communication with overseas clients as well as the distribution of products without agency services.

Direct export is used by merely $7.4 \%$ of respondents, while $3.3 \%$ of them rely exclusively on cooperation with other exporters in delivering their products to overseas clients. The study indicates that the majority of companies (52.1\%) choose to make use of different export modes. Such diversified activities aim to strike the right balance between the particular export modes.

The results of the study indicate that $20.6 \%$ of exporters use different export modes of entry. No correlations are recorded between the adopted strategy and the company's characteristics. Only 20 companies in this group ( $14.2 \%$ of the entire sample) indicate other specific entry modes:

- overseas subsidiary (sales office) - 8 respondents,

- overseas daughter company -7 respondents,

- production facility -5 respondents,

- assembly plant -4 respondents,

- sale of licences -3 respondents,

- joint venture -3 respondents.

It should be noted that most respondents (13 out of 20 ) indicate only one different entry 


\section{Fig. 3: Export modes applied by Polish companies $(\mathrm{N}=121)$}

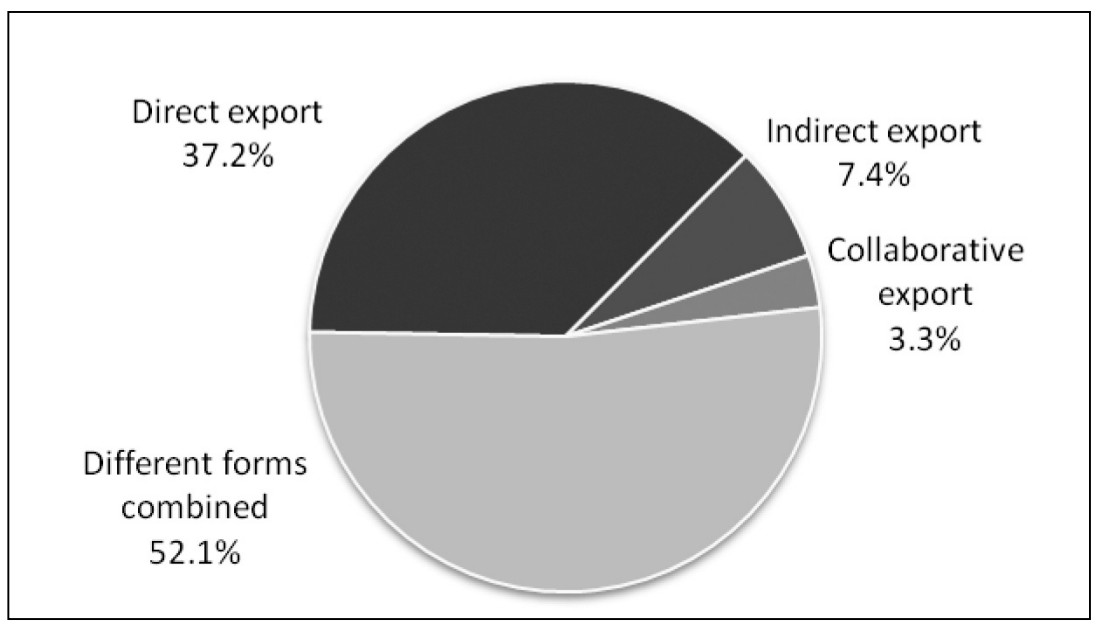

mode. Four companies use two additional entry modes, two exporters use three entry modes, while one of the respondents chooses a highly diversified method resorting to as many as five different entry and business presence modes.

One of the major dimensions of a foreign market entry mode relates to organizational issues - decisions concerning the number of target markets and the order of market entries. Companies can adopt a waterfall, a sprinkler or mixed strategies [1, p. 42-49].

In the conducted survey, Polish exporting companies indicate the adopted foreign market entry mode (from the organizational perspective). The results are presented in Figure 4.

The majority of respondents $(70.3 \%)$ adopt a gradual mode of entering into foreign markets, following the waterfall strategy. It is, as declared by the surveyed companies, a slow entry divided into phases, combined with the process of learning and gaining international experience. Nearly $20 \%$ of companies adopt a mix of strategies, originally focusing on one market or a limited number of markets. The gained experience facilitates further simultaneous expansion on a number of new markets. Exporters do indicate that they start simultaneous operations on many foreign markets, but it does not concern all the markets that they actually serve. Answering the previous question in the survey, respondents indicate different years in which they enter into overseas markets, so their adopted entry modes represent a mix of strategies rather than the sprinkler strategy. Some respondents (10.2\%) name a different entry mode. A thorough analysis of the respondent's answers leads to the conclusion that in this particular case, company's decision to enter into new markets are conditioned by external factors (especially the prospective clients' behaviour), and that companies do not adopt any of the aforementioned strategies. It is confirmed by the following statements made by some of respondents: "if we get lucky, we'll make it"; "let's just wait for customer orders"; "it depends on customer needs"; "we do not have a strategy".

A detailed analysis indicates that the choice between a mix of strategies and the waterfall strategy is dependent on two company characteristics: the number of employees and the number of existing markets. A mix of strategies is more frequently adopted by larger companies and those exporting their products to many countries (see Tab. 6).

Larger companies have easier access to financial and HR resources, and the adoption of a mix of strategies that involve simultaneous entry into a number of markets requires a maximum commitment of company 
Fig. 4: Organizational dimension of foreign market entry modes adopted by Polish exporters $(\mathrm{N}=128)$

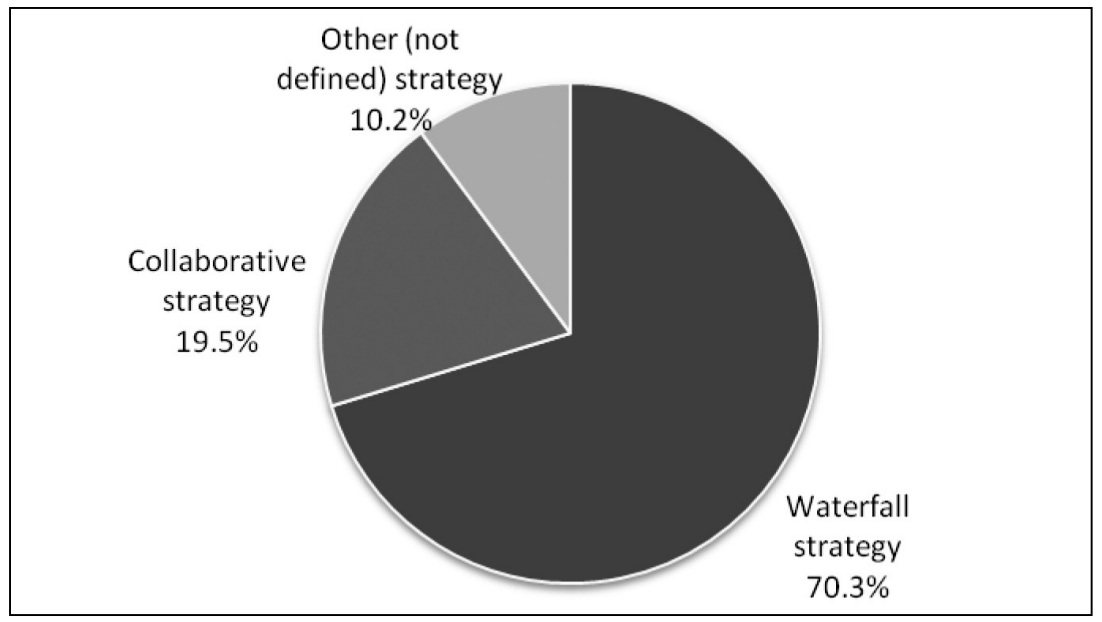

Source: own conception

\begin{tabular}{c|c|c} 
Tab. 6: $\begin{array}{l}\text { A mix of strategies as a foreign market entry mode depending on selected } \\
\text { features of the company }(\mathbf{N}=115)\end{array}$ & $\begin{array}{c}\text { Balance of respon- } \\
\text { dents (\%) }\end{array}$ \\
\hline \multirow{4}{*}{ Variable } & $\begin{array}{c}\text { Value of } \\
\text { the variable }\end{array}$ & $4.17 \%$ \\
\hline \multirow{4}{*}{ Number of employees } & $1-10$ & $16.0 \%$ \\
\cline { 2 - 3 } & $11-50$ & $22.2 \%$ \\
\cline { 2 - 3 } & $51-250$ & $35.0 \%$ \\
\cline { 2 - 3 } & $251-1,000$ & $41.7 \%$ \\
\cline { 2 - 3 } & above 1,000 & $5.3 \%$ \\
\hline \multirow{4}{*}{ Number of countries to which company } & $1-3$ & $15.4 \%$ \\
\cline { 2 - 3 } exports its products & $4-6$ & $21.1 \%$ \\
\cline { 2 - 3 } & $7-10$ & $36.8 \%$ \\
\cline { 2 - 3 } & $11-20$ & $42.1 \%$ \\
\hline
\end{tabular}

Source: own conception

resources in a limited period of time as well as great organizational effort. It may be a likely reason for which smaller companies choose the waterfall strategy. On the other hand, a larger number of existing markets enable companies to gain experience which helps them carry out business operations on a number of markets.

\section{Conclusions}

The conducted study and its results confirm the previously formulated hypotheses concerning reasons for undertaking export activities. In fact, market factors are the most significant reasons for the internationalization of Polish companies $(\mathrm{H} 1)$, with the size of the target 
expansion market being the most frequently indicated factor $(\mathrm{H} 3)$. Political and legal factors, on the other hand, are the least significant internationalization drivers considered by Polish exporters (H2).

The hypothesis $(\mathrm{H} 4)$ which states that the company's size has an impact on the type of international factors and, in a broader sense, that smaller companies are more likely to be driven by defensive factors while larger entities - by offensive ones, is not confirmed by the study. The company's size only affects the decision to start export activities in response to tender enquiries and overseas orders for products. Smaller companies are far more likely to be influenced by this factor. On the other hand, exporters representing the E-100 group are more frequently driven by offensive factors than the members of the $\mathrm{E}-\mathrm{O}$ group

An analysis of the answers given by Polish exporting companies leads to the conclusion that direct export is the most commonly applied method ( $\mathrm{H} 5)$. It is true that only $37 \%$ of companies use direct export as the exclusive export mode, but more than half of respondents apply other forms of export as well.

Additionally, other than export modes of foreign market entry are applied by less than 1 out of 5 Polish exporters (H6). Consequently, it can be assumed that export remains the major form of serving foreign markets, with other forms playing a far less significant role. In the expansion process exporters rely on foreign direct investment by establishing sales representative offices and daughter companies which engage in the distribution of products $(\mathrm{H} 7)$.

The results of the study fully support the hypothesis $(\mathrm{H} 8)$ which states that the waterfall strategy is the most commonly applied foreign market entry mode (more than $70 \%$ of respondents).

This article presents the assumptions that don't allow for broad generalizations. With theoretical and methodological reflection at hand, the presented study could make certain contribution in the scientific formulations process and international business practice development. It can become grounds for deepened scientific discussion on internationalization of marketing, methodology of formulating marketing strategies, their nature and effectiveness of assessment. It is encouraging other researchers to continue with the subject, in international teams.

\section{References}

[1] BACKHAUS, K., BÜSCHKEN, J., VOETH,

M. Internationales Marketing. Stuttgart: Schäffer-Poeschel Verlag, 2001. ISBN 1-86152456-0.

[2] BALÁŽ, P., et al. Medzinárodné podnikanie. 4. vyd. Bratislava: Sprint, 2005. ISBN 80-8908551-2.

[3] DASZKIEWICZ, N. Internacjonalizacja małych $i$ średnich przedsiębiorstw we wspótczesnej gospodarce. Gdańsk: Scientific Publ. Group, 2004. ISBN 83-921075-0-0.

[4] Ekspansja międzynarodowa polskich przedsiębiorstw 2005. Warszawa: KPMG, 2005.

[5] Ekspansja międzynarodowa polskich przedsiębiorstw produkcyjnych 2010. Warszawa: PAlilZ i KPMG, 2010.

[6] GORYNIA, M. (Ed.) Luka konkurencyjna na poziomie przedsiębiorstwa a przystąpienie Polski do Unii Europejskiej. Poznań: Wydawnictwo Akademii Ekonomicznej w Poznaniu, 2002. ISBN 8388760866.

[7] HOLLENSEN, S. Essential of Global Marketing. Essex: Pearson, 2012. ISBN 978-0273-75654-5.

[8] HOLLENSEN, S. Global Marketing: A Decision-Oriented Approach. Harlow: Pearson Education Ltd., 2011. ISBN 978-0273726227.

[9] KOTABE, M., HELSEN, K. Global Marketing Management. Hoboken: John Wiley \& Sons, 2008. ISBN 0-471-75527-3.

[10] KATSIKEAS, C.S., PIERCY, N.F. LongTerm Export Stimuli and Firm Characteristics in a European LDC. Journal of International Marketing. 1993, Vol. 1, Iss. 3, pp. 23-47. ISSN 1069-031X.

[11] KULHAVY, E. Mezinárodní Marketing. Linz: Rudolf Trauner Verlag, 1992. ISBN 8090144-0-3.

[12] LEONIDOU, L.C., Export Stimulation Research: Review, Evaluation And Integration. International Business Review. 1995, Vol. 4, Iss. 2, pp. 133-156. ISSN 0969-5931.

[13] LEONIDOU, L.C., KATSIKEAS, C.S., PALIHAWADANA, D., SPYROPOULOU, S. An analytical review of the factors stimulating smaller firms to export: Implications for policymakers. International Marketing Review. 2007, Vol. 24, Iss. 6, pp. 735-770. ISSN 0265-1335.

[14] MALHOTRA, N.K, ULGADO, F.M., AGARWAL, J. Internationalization and entry modes: a multitheoretical framework and research propositions. Journal of International Marketing. 2003, Vol. 11, Iss. 4, pp. 1-31. ISSN 1547-7215. 
[15] PAN, Y., TSE, D.K. The hierarchical model of market entry modes. Journal of International Business Studies. 2000, Vol. 31, Iss. 4, pp. 535554. ISSN 0047-2506.

[16] PETERSEN, B., WELCH, L.S. Foreign operations mode combinations and internationalization. Journal of Business Research. 2002, Vol. 55, Iss. 2, pp. 157-162. ISSN 0148-2963.

[17] Rocznik statystyczny handlu zagranicznego Polski 2010. Warszawa: GUS, 2010. ISSN 0079-2691.

[18] SHARMA, V.M., ERRAMILLI, M.K. Resource-based explanation of entry mode choice. Journal of Marketing Theory and Practice. 2004, Vol. 12, Iss. 1, pp. 1-18. ISSN 1069-6679.

[19] SVETLIČIČ, M., JACKLIČ, A., BURGER, A. Internationalization of Small and Medium-Size Enterprises from Selected Central European Economies. Eastern European Economics. 2007, Vol. 45, Iss. 4, pp. 36-65. ISSN 0012-8775. [20] TAN, A., BREWER, P., LIESCH, P.W. Before the First Export Decision: Internationalisation Readiness in the Pre-Export Phase. International Business Review. 2007, Vol. 16, Iss. 3, pp. 294-309. ISSN 0969-5931.

[21] TARGALSKI, J. (Ed.) Wptyw integracji europejskiej na rozwój przedsiębiorczości. Kraków: Wydawnictwo Uniwersytetu Ekonomicznego w Krakowie, 2009. ISBN 97883-7252-459-1.

[22] WIKTOR, J.W, CHLIPAŁA, P. (Eds.) The Marketing Strategies of Polish Companies in International Markets. Warsaw: Polish Economics Publishers (PWE), 2012. ISBN 97883-208-2042-3.

[23] WIKTOR, J.W., OCZKOWSKA, R., ŻBIKOWSKA, A. Marketing międzynarodowy. Zarys problematyki. Warszawa: PWE, 2008. ISBN 978-83-208-1788-1.
[24] WITEK-HAJDUK, M.K. Strategie internacjonalizacji polskich przedsiębiorstw $w$ warunkach akcesji Polski do Unii Europejskiej. Warszawa: Oficyna Wydawnicza, Szkoła Główna Handlowa w Warszawie, 2010. ISBN 978-83-7378-547-2.

[25] ZAPLETALOVÁ, Š. Prístupy k internacionalizaci podnikatelských aktivit českých podnikú. E+M Ekonomie a Management. 2012, Vol. 15, No. 4, pp. 84-95. ISSN 1212-3609.

[26] ŻABIŃSKI, L. Zarys metodyki case research na cele badań zachowań marketingowych. In: MAZUREK-ŁOPACIŃSKA, K. (Ed.) Badania marketingowe. Metody. Nowe technologie. Obszary badań. Warszawa: PWE, 2008. ISBN 978-83-208-1777-5.

[27] ŻBIKOWSKA, A. Eksport jako forma internacjonalizacji polskich przedsiębiorstw. Uwarunkowania i strategie. Kraków: PTE, 2012. ISBN 987-83-61686-02-06.

prof. Ing. Jaroslav Ďad'o, PhD. Matej Bel University Banska Bystrica

Faculty of Economics

Department of Corporate Economics and Management jaroslav.dado@umb.sk

prof. dr. hab. Jan W. Wiktor Cracow University of Economics

Faculty of Management Department of Marketing jan.wiktor@uek.krakow.pl

dr. hab. Agnieszka Źbikowska Cracow University of Economics Faculty of Management Department of Marketing zbikowska@uek.krakow.pl 


\title{
Abstract
}

\section{FOREIGN MARKETS ENTRY MOTIVES AND STRATEGIES OF POLISH EXPORTERS}

\author{
Jaroslav Ďad’o, Jan W. Wiktor, Agnieszka Żbikowska
}

The article presents the results of research on the strategy of Polish companies that export their products to foreign markets. It presents motives, conditions and forms of expansion and is comprises of three parts. In the first one, the theoretical aspects of a company's internationalization are discussed, with stress on motives and forms of entering foreign markets. The second part is concerned with the complex problems regarding methodology of research - goals, hypotheses, methods and description of study sample are the main focus here. The synthetic, summation of the results of the study are presented in the third part.

The study verifies the hypotheses regarding motives of internationalization and concrete forms of entering foreign markets. The most powerful premises to internationalize Polish companies are market motives. The relationship between the size of the company, decision to start export goods and the nature of expansion (offensive, as well as defensive) has been ascertained. One of the strong motives for internationalization among companies belonging to SME group, were encouragements and invitations for cooperation from foreign partners. However, the main strategy was direct export, complemented by other forms of expansion, of lesser importance. In the expanding process Polish exporters took advantage of direct investments, via establishing divisions and subsidiary companies that deal with distribution of products. The waterfall strategy proved to be the most common in entering foreign markets - used by roughly $70 \%$ of the examined exporters.

The research could be a contribution into the process of scientific examination and development of international business practice. It can also provide a ground for further discussion on marketing internationalization, methodology of formulating marketing strategies, their nature and assessing their effectiveness on international markets. Last but not least it can encourage more such scientific studies and research conducted by international teams of scholars.

Key Words: Internationalization, export motives, entry modes, Polish exporters.

JEL Classification: L2, M21, M31.

DOI: 10.15240/tul/001/2015-2-010 